\title{
Effect of Entrepreneurial Orientation on Profitability of Women Owned Enterprises in Pokhara City, Nepal
}

\author{
Pratikshya Bhandari ${ }^{1} \&$ Fuangfa Amponstira ${ }^{2}$ \\ ${ }^{1}$ Ph.D. Candidate, Management, School of Management, Shinawatra University, Thailand \\ ${ }^{2}$ Ph.D., Management, School of Management, Shinawatra University, Thailand \\ Correspondence: Pratikshya Bhandari, Management, School of Management, Shinawatra University, Thailand. \\ Fuangfa Amponstira, Management, School of Management, Shinawatra University, Thailand.
}

Received: July 24, 2020

Accepted: September 4, 2020

Online Published: September 17, 2020

doi:10.5539/ibr.v13n10p66

URL: https://doi.org/10.5539/ibr.v13n10p66

\begin{abstract}
Entrepreneurial orientation is defined as an organization's strategic orientation, which seizure an organization's strategic making practices, managerial philosophy, and the organization's behavior, which are entrepreneurial. This study investigates the effect of entrepreneurial orientation on the profitability of women-owned enterprises in Pokhara City, Nepal, through mixed research method qualitative and quantitative analysis. The primary data were obtained from an in-depth interview with two experts of government offices and sixteen personnel/founder from women-owned enterprises. Secondary data were collected from Nepal Government and The World Bank. The study found that entrepreneurial orientation and its various dimension (Proactiveness, Innovativeness, Risk-taking, Competitive Aggressiveness, and Autonomy) are the major influencing factors to increase the profitability of women-owned enterprises.

Furthermore, in the present context, women-owned enterprises should concentrate more on innovativeness to achieve profitability. Women should overcome all the issues and challenges they face at the personal level, social level, financial level, and government level, which will be vital in improving women-owned enterprises' business growth. The finding of this study helps the women-owned enterprises be more entrepreneurial to sustain and grow in the competitive market environment amid huge challenges and barriers.
\end{abstract}

Keywords: entrepreneurial orientation, firm's performance, women-owned enterprises, profitability

\section{Introduction}

Women entrepreneurship has been emerging and considered vital in developing the whole country. Regardless of the size and nature, all the companies need to constantly seek new opportunities to grow and succeed in today's rapidly changing business environment, where possessing an Entrepreneurial Orientation (EO) has been recognized as a key beneficial element (Wiklund \& Shepherd, 2011). Entrepreneurial orientation has recently been recognized as one of the most significant factors for a firm's growth and profitability (Wijetunge \& Pushpakaumari, 2013). Similarly, to increase productivity and the organization's growth, entrepreneurial orientation plays a huge role (Aloulou \& Fayolle, 2005). This study is based on Lumpkin and Dess's concept, five-dimension EO, namely proactiveness, innovativeness, risk-taking, competitive advantage, and autonomy (Lumpkin \& Dess, 1996). The importance of women entrepreneurship for economic development is widely accepted and recognized. National Economic Census 2018 shows that 29.8 percent of the enterprises are owned by women, 247,882 enterprises (Government of Nepal, 2019). Almost one-third of Nepalese businesses are owned by women, which indicates women in Nepal are empowering and coming out from domestic chores. Therefore, women-owned enterprises play a vital role in the Nepalese economy.

There are various roles an entrepreneurial orientation plays in the enterprises. Some researchers conducted their studies on the influence of entrepreneurial orientation on business performance. Numerous studies are related to the women entrepreneurs and the firm's performance done by (Tuladdhar, 1996; Dwibedi \& Lalan, 2015; Gautam, 2016). In their respective studies, they have discussed issues related to entrepreneurial orientation. They found that adopting EO dimensions in firms will help them create or sustain a high-performance level. Aforesaid specific study in the entrepreneurial orientation and profitability of women-owned enterprises still lacks, particularly in Nepal. There lies a research gap that needed to be filled. So, this study tries to fill this gap. This 
research adopts an in-depth interview method to ensure the well-organized and well-suited to this study (Diehl \& McDonald, 2001).

Entrepreneurial orientation is necessary for an entrepreneurial organization (Hirobumi et al., 2010). Therefore, this study attempts to examine how EO can contribute to the profitability of women-owned enterprises. By analyzing the relationship between EO and women driven organizations, this study provides useful insights to the owner of enterprises in Pokhara city to be entrepreneurially oriented in their businesses. Moreover, it will state whether there is any effect of entrepreneurial orientation on the firm's profitability.

\section{Literature Review}

Hereunder, the brief related literature to develop the concept of Entrepreneurial Orientation and firm's performance.

\subsection{Entrepreneurial Orientation}

Entrepreneurial orientation is defined as the process, practices, and decision-making activities that lead to new entry (Lumpkin \& Dess, 1996). The term new entry can be either enter the new market or enter the existing market with a new product and service; it was the first time when (Miller, 1983) introduces the concept of entrepreneurial orientation. Nonetheless, he did not use the term entrepreneurial orientation in his preliminary writing (Covin \& Lumpkin, 2011). In his preliminary writing, Danny Miller proposed a definition which states that an entrepreneurial firm is that one which involves product-market innovation, with a risky venture with proactiveness, beating competitor. The three vital dimensions are of entrepreneurial orientation are proactiveness, innovativeness, and risk-taking, which creates a higher-order indicator of firm-level entrepreneurship (Covin \& Wales, 2012).

Based on the effort of (Miller, 1983; Covin \& Slevin, 1989), it shaped the concept of entrepreneurial orientation, which has been broadly used in modern entrepreneurship and management literature. Initially, Covin and Slevin (1989) theorized the three dimensions of entrepreneurial orientation, i.e., proactiveness, innovativeness, and risk-taking, as a basic unidimensional strategic orientation. They urged that it should be combined when researching the field of entrepreneurship. Well, Johan \& Lumpkin (2009) developed a nine-item response scale to measure the organization's significant level of entrepreneurial orientation. With ensuring the previous concept of (Miller, 1983; Covin \& Slevin 1986) later, (Lumpkin \& Dess, 1996) suggested that entrepreneurial orientation can be considered as a multidimensional phenomenon by adding two-dimension which are competitive aggressiveness and autonomy. These two additional dimensions describe the area of entrepreneurial orientation in detail. The dimension of (Lumpkin \& Dess, 1996) described by entrepreneurial orientation includes proactiveness, innovativeness, risk-taking, competitive aggressiveness, and autonomy. The development of entrepreneurial orientation with a five-dimension approach is broadly dominant in entrepreneurial orientation research.

The first dimension is proactiveness as proactiveness is the first mover strategy, which is considered a good strategy for capitalizing on a market opportunity. Seeking for opportunities and move forward to the launching of new products or services in the market in advance ahead of the competition and beforehand in expectation of future demand (Miller, 1983; Lumpkin \& Dess, 2001). Secondly, innovations; creativeness is the initial step by the entrepreneur, endorsing the implication of innovation within the concept of entrepreneurial orientation as a serious accomplishment feature (Lumpkin \& Dess, 1996). Third is risk-taking; the firms with entrepreneur orientation are characterized by risk-taking attitude as it includes important responsibilities with aiming to have high returns by taking opportunities existing in the market (Lumpkin \& Dess, 1996). The capability that has been defined as the willingness to catch the opportunities which have a huge possibility of losses and, on the other hand, with significant performance differences is defined as the risk-taking ability (Morris et al., 2010). Fourth is competitive aggressiveness; competitive aggressiveness is defined as the company's effort to outperform its business rivals, illustrious by strong, aggressive strategies and forceful strategy towards the competitor action to reach the aim of the organization as well as to enlarge the business status (Lumpkin \& Dess, 2001). And finally, fifth is autonomy; autonomy is an independent action that constructs the ability to take a single decision or group to bring the new venture with a new concept without any organization (Lumpkin \& Dess, 1996).

\subsection{Firm's Performance}

A firm's performance means combining a firm's objectives and a firm's resources (Jenatabadi, 2015). It is mainly needed to determine the applicable performance indicator and their relation to the objectives and activities. Performance is referred to as the complex concept that has been measured using an array of indicators (Lumpkin $\&$ Dess, 1996). From the viewpoint of organization, performance means about the organization's management, 
the way of delivering the values of the organization to the customer and shareholders (Wu \& Zhao, 2008). The firm's performance is the firm's effectiveness, including firm financial and non-financial performance (Venkatraman \& Ramanujun, 1986). The financial performance of a firm is important; however, it does not include overall firm performance. The dimension of a firm's financial performances measurement is sales growth, profit growth, and profitability (Venkatraman \& Ramanujun, 1986). According to Mitchell (2002), organizations' performance is affected by two major factors: organizational motivation to grab performance objectives and organizational capacity to grab performance. Finally, the external environment and organizational performance impact can be measured by four elements, i.e., effectiveness, efficiency, relevance, and financial viability.

\subsection{Entrepreneurial Orientation and Firms Performance}

The reason behind the rapid growth of interest in entrepreneurship is due to the conception that entrepreneurship can boost the performance of new and established enterprises (Covin \& Slevin, 1991). The relationship between EO and firm performance has been extensively discussed conceptually and empirically in previous studies, and the majority were stated a positive relationship between them (Lumpkin \& Dess, 1996; Fairoz et al., 2010). Most researches directed to entrepreneur orientation such (Miller 1983; Lumpkin \& Dess 1996; Birech et al., 2018; Adim et al., 2018) investigated the impact of entrepreneurial orientation with different dimensions on business performance. They found that entrepreneur orientation is positively correlated with business performance. In studies, Rauch et al. (2009) show that EO and organizational performance have a positive relationship.

\section{Research Methodology}

This research is a qualitative and quantitative analysis. For qualitative analysis, data were collected by in-depth interviews (Diehl \& McDonald, 2001). The researcher defines the population as women-owned enterprises and government officers in Pokhara City, Nepal. Following Creswell (2016) recommends 5 - 25 could be a sample size in qualitative research. Therefore, the researcher collects the data from 2 government officers who have been working in the related field with high rank and 16 women entrepreneurs who have their businesses located in Pokhara City.

The researcher uses purposive sampling to select the samples. Mostly questions are developed from the concept of entrepreneurial orientation by (Lumpkin and Dess, 1996). Before going to the interview process, the questions were tested by experts of related fields using item objective congruence (IOC test). The lists of women-owned enterprises are gathered from the Pokhara \& Lekhnath Chamber of Commerce and Industry and the Department of Cottage and Small Industries. Likewise, the performance was measure with the profitability of the interviewee's opinion. Content analysis was done for qualitative data. In the process, interviews are transcribed, coded to be interpreted. It will clarify the respondents' opinions to analyze all the data obtained from the in-depth interview.

On the other hand, in quantitative analysis, self-employed women, which means women who owned their business is compared with the World, South Asia, and Nepal. And the percentage of women-owned enterprises in different sector are analyzed. The result of the quantitative analysis is presented in the figure.

\section{Result and Discussion}

This study employs both quantitative and qualitative methods. It studies the self-employed women, and the effect of entrepreneurial orientation on the profitability of women-owned enterprises has been presented based on the study result.

\subsection{Quantitative Analysis}

It studies the women-owned enterprises of the World, South Asia, and Nepal. Similarly, the percentage of women-owned enterprises in different sector are analyzed.

\subsubsection{Self-Employed Women}

Self-employed women of the World, South Asia, and Nepal from 2010 to 2019 have been analyzed. In 2010, self-employed women in the World were 51.7 percentage, south Asia 85.9 percentage, and in Nepal 91.9 percentage. The percentage of self - employed women in each year is decreasing slightly in the World. South Asia and Nepal as well. Till 2019 self-employed women in the World are 46.8 percentage, South Asia has 75.2, and Nepal has 89.3 (The World Bank Group, 2020). The percentage of self-employed women in the World, South Asia, and Nepal are presented in figure 1. 


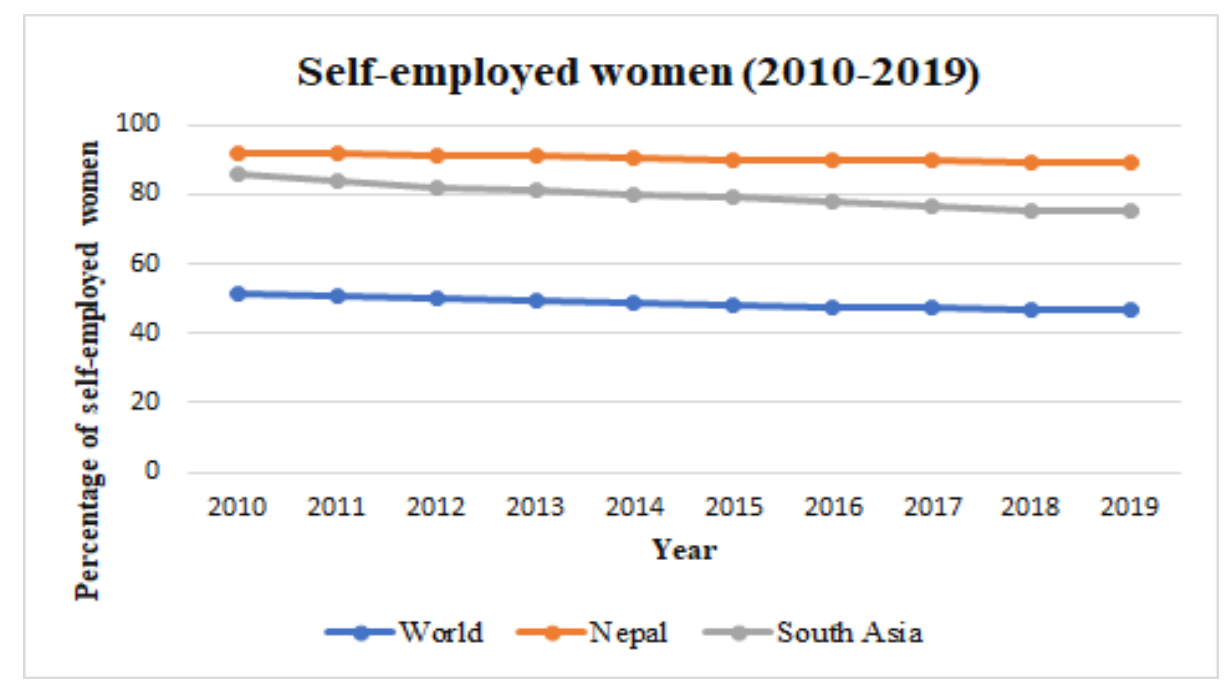

Figure 1. Self-employed women 2010-2019 (modeled ILO estimate)

Source: The World Bank Group, 2020

\subsubsection{Women-Owned Enterprises in a Different Sector}

According to the National Economic Census 2018 shows that women own 29.8 percent of the enterprises. The highest percentage of women-owned enterprises are in wholesale and retail trade, repair of motor vehicles and motorcycles, which is 62.05 percentage, accommodation, and food service activities 20.47 percentage. Similarly, manufacturing 9.45 percentage, education 0.89 percentages, agriculture, forestry, and fishing 0.80 percentage, human health and social work activities 0.66 percentage and other 5.68 percentages (Government of Nepal, 2019). The percentage of women-owned enterprises in different sectors is presented in figure 2 .

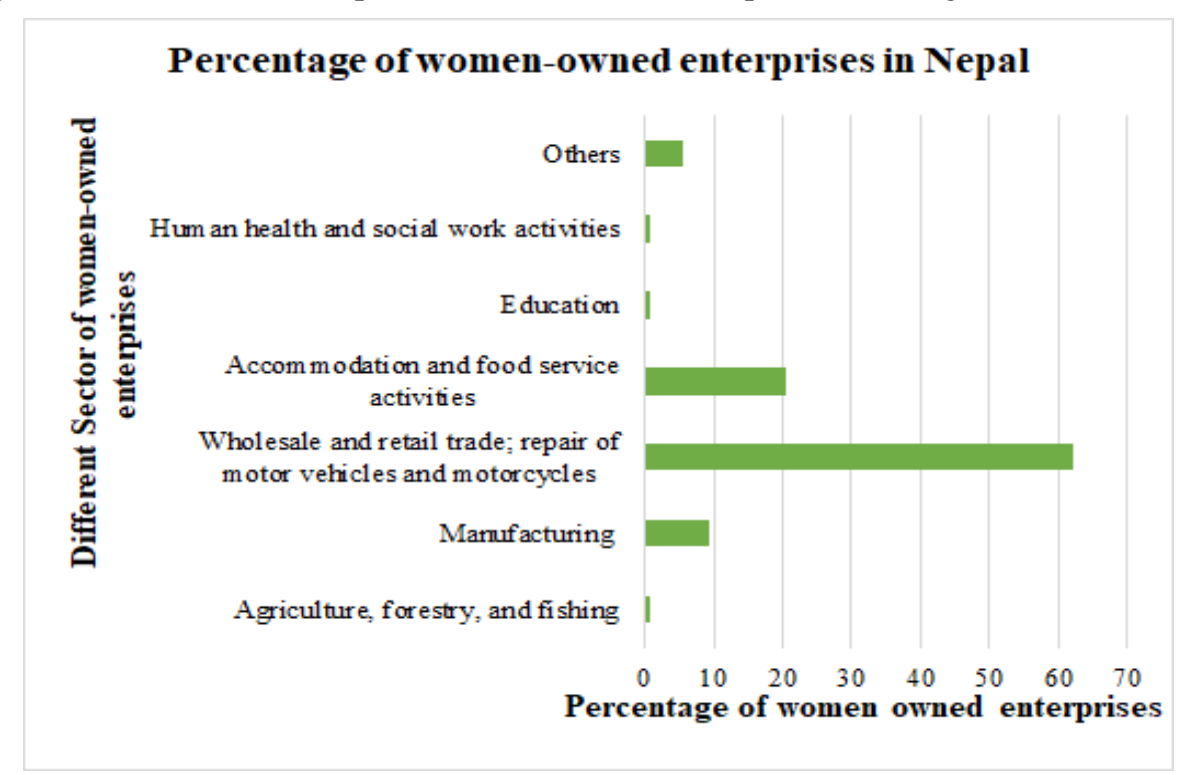

Figure 2. Percentage of women-owned enterprises in Nepal

Source: Government of Nepal, 2019

\subsection{Indicators of Proactiveness}

Qualitative analysis has been made to identify the indicators of proactiveness. In this regard, the responses of the interviewee are presented below: 


\subsubsection{Imitative Towards Introducing a New Product}

Introducing something is new is crucial to sustaining in this competitive market as it is a series of actions. It is all about the personal quality and the power to take charge before others do, which shows a willingness to do something different and take responsibility. The point that strikes in mind and manipulates in real life in introducing a new product is important from the market viewpoint as it enhances the women-owned enterprises.

\subsubsection{Focus on Market Demand}

Reach to customer expectation is the primary duty and responsibility of all businesses or organizations. What customer wants? is very necessary. Focus on customer desire and demand and fulfill the market demand is developing the women-owned business and a way to build the business profile. Part of serving customers helps to learn how to predict what they will want, how much of it, and when to serve customers well while still making a profit.

\subsubsection{Imitativeness Towards Competitor}

Normally, always we cannot do unique things; sometimes, we have to search in the market about other new or unique services or products and copy their uniqueness. It is real that the product or service we copy and slightly modify from other competitors gives a great output.

Therefore, based on the above discussion, imitative towards introducing a new product, focus on market demand, and imitativeness towards competitors is the key indicator of proactiveness in entrepreneurial orientation.

\subsection{Indicators of Innovativeness}

Qualitative analysis has been made to identify the indicators of innovativeness. In this regard, the responses of the interviewee are presented below:

\subsubsection{Emphasis on Research and Development}

Research and development are the first phase of any process leading to innovation. It shows the long vision of a business. Research and development consist of investing the fund to product and service, enabling the company to earn. Research improves the manufacturing process so that the cost can be reduced whereas an increase in enterprise profit. Moreover, emphasis on research and development activities within the business offers a tremendous advantage as it allows us to create an environment to integrate new concepts and processes.

\subsubsection{Introduction of New Product}

People want and desire change according to the time phase. To meet the market, desire some innovation is needed, i.e., introducing a new product. Most of the successful women-owned enterprises highlighted the importance of the implementation of a new product introduction process. In today's competitive market, companies must develop the right product at the right time at the right price. The significance of introducing new products is to reduce development costs, faster time to market, more efficient manufacturing, and improved product quality.

\subsubsection{Change to the Current Product}

Change is important in business. It allows a company to meet the dynamic needs of its customer and creates growth opportunities. Change does not mean it has to be changed; it also comes to modify an existing product. Sometimes, in case of doing some handicraft works, if we change just the design or color, people think it as a new product. The theme is that the product should satisfy the customer and meet the customer desire.

Consequently, based on the above discussion, emphasis on Research and Development, introduction of a new product, and change to the current product are the key indicator of innovativeness in entrepreneurial orientation.

\subsection{Indicators of Risk-Taking}

Qualitative analysis has been made to identify the indicators of risk-taking. In this regard, the responses of the interviewee are presented below:

\subsubsection{Willingness to Take Risk}

A willingness to take risks can give women entrepreneurs the power to do more. Business risks can move a business ahead. A risk-taking spirit might see opportunities where others do not see and spot trends well before the market is saturated.

\subsubsection{Dealing with Uncertainty}

Most of the time, we used to take unknown steps in business. Every business experiences uncertainty at some 
phase. It occurs in case of acquisitions, new ownership, shifting in strategy, or a new leader. Uncertainty creates huge stress, the longer uncertainty harder to resolve. However, once it reaches a certain high level, it will destroy the organization. People should know the risk of what it creates, make a decision, and act urgently and take the lead and make uncertainty certain.

\subsubsection{Exploring Potential Opportunities}

Risk shows the new opportunity. It creates a new and possible opportunity which women entrepreneurs have to identify and explore.

As per the above discussion, willingness to take risks, deal with uncertainty, and explore potential opportunities are the key indicators of risk-taking on entrepreneurial orientation.

\subsection{Indicators of Competitive Aggressiveness}

Qualitative analysis has been made to identify the indicators of competitive aggressiveness. In this regard, the responses of the interviewee are presented below:

\subsubsection{Forceful Reaction to Competitor Action}

Yes, it is true in this competitive market without being interested also we need to enter the competitive market. To sustain in the market, we have forcefully entered the market to tackle the competitor's action. In such a case, women entrepreneur should focus on price-cutting and increasing spending on marketing, quality, and production capacity introduced of new product or service or whatever the market adopt we must follow the competitor action.

\subsubsection{Willingness to be Unconventional}

They are uniquely doing something. Introducing a new product or service in a unique approach in the market is the way to compete in one's style. Once when women entrepreneur recognizes what the strength you have, which makes you unique to do this and then flourish, your potential is. Focus on the skills and do the best to serve others with unique abilities.

\subsubsection{Avoid Competition}

Women entrepreneur does not want to enter the market as it gives a huge burden mentally and financially and full of risk. It creates a huge variation in price as business face loss.

The above discussion concluded that avoiding the competition, forceful reaction to competitor action, and willingness to be unconventional are the key indicators of competitiveness on entrepreneurial orientation.

\subsection{Indicators of Autonomy}

Qualitative analysis has been made to identify the indicators of autonomy. In this regard, the responses of the interviewee are presented below:

\subsubsection{Enhance Strength and Identify Opportunity}

The power that shapes your work in the ways that allow you to perform at your best refers to autonomy. Uplift the strength that is within you and perform the best work. And in the journey of quality improvement and know the organization's weakness when someone recognizes that an opportunity for improvement exists.

\subsubsection{Independence}

Independence boost confidence, reduce over faith on others, promotes happiness, increase confidence, rises sense of achievement, and encourages well decision-making so that women entrepreneur can handle things on their own. Being independent indicates having the ability to make decisions oneself. For instance, financial independence brings a sense of freedom by permitting a person to make their own monetary decisions. Similarly, emotional independence reduces stress, enhances happiness, and helps people handle challenging situations in their lives and make personal decisions.

\subsubsection{Freedom and Flexibility}

Freedom and flexibility are important in terms of business. Freedom is widely explained as a basic human right. Given the flexibility to women, entrepreneur affords people freedom where freedom people can perform better. It translates into higher productivity levels, loyalty, and engaged employees.

As per the above discussion, enhance strength and identify opportunity, independence, and freedom and flexibility are the key indicators of autonomy on entrepreneurial orientation. 


\subsection{Influencing Factor for the Success and Profitability of Enterprises}

The investigation was made on identifying the most influencing factor that helps to the success of women-owned enterprises and the profitability range of women-owned enterprises.

\subsubsection{Innovativeness}

In a simple sense, we can describe innovativeness is about the new product or service a company has introduced to the market. Innovativeness is naturally linked to entrepreneurship as entrepreneurs introduce new products and services into the market. Innovation is crucial in the workplace since it gives the advantage to jump in the market faster and create a better connection to other emerging markets, which provides a bigger opportunity. Once a business adopts an innovative culture, it blooms so that it can fulfill the thirstiness of people who wants something new every morning.

\subsubsection{Proactiveness}

Proactive behavior includes acting in advance of a future condition. People are seeking new products and services according to the interval of time. To grab the customer demand and fulfill the need is the fruitful action in this hungry market. It is the ability to get future possibilities and threads and start taking actions. It prevents failures and making things happen rather than just adjusting the situation. Also, proactiveness adds entrepreneurial action features to anticipate future opportunities related to the product and the market and consumer demand.

\subsubsection{Autonomy}

In this era, no one wants to stay in someone lower than themselves. People need to perceive that they have choices, that what they are doing is of their wish or desire, and that they are the source of their actions, and people need freedom and flexibility to do all things. It boasts a team or an individual to come up with an established idea or concept. Autonomy is not only for the owner; it is for the employee too. A free environment or a friendly environment encourages an employee to do work effectively and put more effort into giving a better output.

\subsubsection{Risk-taking}

Generally, it is natural that women entrepreneurs are not eager to take risks in their business; it's a fear of losing. Women want to be on the safe side. Risk-taking creates an unexpected opportunity that boosts confidence and helps to stand out. Risk gives two results, its booms, or it goes down; failure teaches the lessons and shows the new paths and encourage them to do more. Success does not lie in your lap; it comes if you dared to face risk. So, risk-taking is a benefit for the success of the business.

\subsubsection{Competitive Aggressiveness}

Competitive aggressiveness is a way to directly challenge competitors rather than avoid them. It teaches a lesson to be constant in the market as it also teaches to act as per situation arise. New business is more likely to fail than a settled business, so, for the new business, taking an aggressive stand and increasing the competition is needed for business survival.

Innovativeness is the most important dimension of entrepreneurial orientation for women-owned enterprises' better performance to increase profitability, followed by proactiveness, autonomy, risk-taking, and competitive aggressiveness.

\subsection{Performance of Your Enterprises According to Profitability in the Past Year}

As no one wants to disclose the profitability exactly. So, the researcher gives the option to answer the Likert Scale's profitability as $1=$ very low profit, $2=$ low profit, $3=$ normal profit, $4=$ high profit, and $5=$ very high profit; therefore, it is easy for the owner to answer the question. Most of the respondent's state that they are in high profit as these enterprises are satisfied with their work and outcomes and forecast to do more in the future for achieving more profitability. Similarly, the few respondents state that they are in normal profit as they are in a growing phase of their business. Lastly, very few respondents stated that the enterprises are in a very high profit; it denotes that the enterprises are satisfied and happy in terms of profitability.

This result shows that women-owned enterprises are in normal profit, high profit, and very high-profit range. Women are making more effort to bring in this condition for their business.

\subsection{Problem, Solution, Policy, and Benefit for Women-Owned Enterprises}

The investigation was made to identify the problem faced by women. And the solution to the problem from the side of women and government and policy and benefit that women-owned enterprise. 


\subsubsection{Personal Issues}

Women must play a dual role, housewife, and entrepreneur. It is difficult for them to play these two roles simultaneously way. The next, most women are economically dependent upon their husbands or with family and limited liberty at home, so each decision should pass through the family with condition, but all the family will not be cooperative and allow to do. However, some women have a facing problem by themselves, like lack of communication skills, shyness, and lack of confidence.

Its duty of women to make family happy and handle business. At first, women should keep a clear vision about their business and trust the family about the work so that family will understand and support it. Next is about personal weakness, build up confidence, and learn about the skill or technique either by your effort or with the help of teaching institute and learn to communicate in a good way to be easy to work in the business platform.

\subsubsection{Social Issues}

In a theoretical way, women and men are equal, but partially it is still lacking. The majority of women face the problem of a wrong attitude and narrow vision of society against them. Women are facing the problem of public prejudice and criticism. Some women cases even speak freely with men for business purposes, also suffer from backbiting. As a result, it disturbs and destroys the family life of women too.

To add enthusiasm to the women entrepreneur, if a government conducts the program of awarded the best women entrepreneur in a different sector, such a program will help women put more effort into what they do. And encourage the rest of women to start the business and give a good message to the society so that society way of thinking towards women entrepreneurs may change.

\subsubsection{Financial Issues}

Financial problem is another major problem of women-owned enterprises. It is trouble getting the loan in the necessary time because of banks' unsympathetic attitude towards women entrepreneurs. It occurs because of a lack of trust. And it is true; also, all banks need a clear document of collateral security and margin money; however, it is difficult to provide it because, in our male-dominated society, women have no or limited property.

Nowadays, there is a huge benefit woman achieve when register for the enterprises. According to the business style or type, the women will get a 30\% to 50\% discount on registration. It cost only Rupees 200 when a woman registers enterprises; however, when a man registers enterprises, it costs Rupees 3100 . This beneficial policy is very helpful from the viewpoint of finances for women who want to raise their enterprises. In Pokhara Metropolitan city, especially policy is built for women entrepreneurs as an interested woman who wants to start a business can get up to 10 million loans in a $3 \%$ interest rate.

\subsubsection{Government Issues}

Governments are implementing various support schemes for the development of women entrepreneurs. Unfortunately, government assistance is lacking at the time of starting an enterprise. Meanwhile, the procedures of obtaining government assistance are very complicated and time-consuming; it needed a different paper of formalities. It's a lack of proper information about government assistance. However, government officials' corrupted and exploitative nature is also the problem of women entrepreneurs in utilizing government benefit and support.

Regarding the cost of registration of enterprises by women, the government has given a huge discount. Even though the public is not aware of the government's rules and policies if polices are fully flow by the grass level office such as the company registration office or vat office where there is a direct link with the public. After that, the public will be aware of the policy so that women are motivated to do something.

The policy about women-owned enterprises that developing women entrepreneurship presents a precious instrument for enhancing Nepal's economy and empowering women. According to the constitution, the constitution provides protections for women, including equal pay for equal work. According to the industrial policy that lies under the women-owned enterprises are: if a woman entrepreneur wants to establish an industry inside the industrial states, with having a discount price, a woman can get the place. Similarly, when requiring a loan to export their products, they can send their loan application to the ministry through the business registration office, along with their recommendation. And also, upon receiving the application, if the loan is deemed appropriate, an amount as assigned by the ministry can be provided as an "export loan" out of (public) finds based on a necessary mortgage under clause (cha) of sub-section (1) of section (47) of the company act.

\section{Conclusion and Recommendation}

The percentage of self-employed women has slightly decreased yearly in the World, South Asia, and Nepal. In 
Nepal's context, the highest women entrepreneurs are in the sector of wholesale and retail trade, repair of motor vehicles and motorcycles, which is 62.05 based on quantitative analysis. From the qualitative analysis, the dimension of entrepreneurial orientation applied by women enterprises is proactiveness, and its indicators emphasize research and development, the introduction of a new product, and change to the current product. Similarly, innovativeness indicators are an emphasis on research and development, the introduction of new products, and change to the current product. Similarly, the indicator of risk-taking is willing to take risks, dealing with uncertainty, and exploring the potential opportunity. Competitive aggressiveness indicators are a forceful reaction to the competitor's action, willingness to be unconventional, and avoid competition. And finally, autonomy indicators are enhancing strength and identifying an opportunity, independence, and freedom \& flexibility. From the discussion, innovativeness is the most important dimension of entrepreneurial orientation for the better performance of women-owned enterprises to increase the profitability followed by proactiveness, autonomy, risk-taking, and competitive aggressiveness. However, Gautam (2016) states that there is no correlation between innovativeness and handicraft enterprises' performance in Nepal. Women should be strong and know in terms of personal, social, financial, and government issues. At first, women must build self-confidence and eager to do something, and secondly, women are unclear about the government polices till now. There is a priority when women registered an enterprise and run in terms of registration and renewal process. This beneficial policy is very helpful from the viewpoint of finances for women who want to raise their enterprises. This study will justify the reason and show the important dimension that enhances the business profitability and techniques to boost women-owned enterprises. There is enough scope to conduct further study on study of entrepreneurial orientation to the SMEs, service sector, common goods manufacture companies and many more and in different cities with large sample size.

\section{References}

Adim, V., Tamunomiebi, C., \& Dagogo, M. (2018). Entrepreneurial Orientation and Women Entrepreneurs' Contribution to Household Livelihood and Sustenance in Rivers State. World Journal of Entrepreneurial Development Studies, 2.

Aloulou, W., \& Fayolle, A. (2005). A conceptual approach of entrepreneurial orientation within small business context. Journal of Enterprising Culture, 13, 21-45. https://doi.org/10.1142/S0218495805000045

Birech, F. K., Karoney, L. C., \& Alang'o, D. O. (2018). Relationship Between Entrepreneurial Orientation and Performance of Small and Medium Women Owned Enterprises In Uasin Gishu County, Kenya. International Journal of Small Business and Entrepreneurship Research, 6, 57-79.

Central Intelligence Agency. (2019). The World Factbook. Retrieved August 30, 2020, from https://www.cia.gov/library/publications/the-world-factbook/geos/np.html

Covin, J. G., \& Lumpkin, G. (2011). Entrepreneurial orientation theory and research: Reflections on a needed construct. Entrepreneurship theory and practice, 35, 855-872. https://doi.org/10.1111/j.1540-6520.2011.00482.x

Covin, J. G., \& Slevin, D. P. (1989). Strategic management of small firms in hostile and benign environments. Strategic management journal, 10, 75-87. https://doi.org/10.1002/smj.4250100107

Covin, J. G., \& Slevin, D. P. (1991). A conceptual model of entrepreneurship as firm behavior. Entrepreneurship theory and practice, 16, 7-26. https://doi.org/10.1177\%2F104225879101600102

Covin, J. G., \& Wales, W. J. (2012). The measurement of entrepreneurial orientation. Entrepreneurship theory and practice, 36, 677-702. https://doi.org/10.1111\%2Fj.1540-6520.2010.00432.x

Covin, J., \& Slevin, D. (1986). The development and testing of an organizational-level entrepreneurship scale. Frontiers of entrepreneurship research.

Creswell, J. W. (2016). Qualitative inquiry and research design: Choosing among five approaches. Sage publications.

Diehl, L. A., \& McDonald, D. (2001). Conducting an in-depth interview. University of Florida Cooperative Extension Service, Institute of Food.

Dwibedi, \& Lalan. (2015). Women entrepreneurship and innovations: A critical analysis. Academic Voices: A Multidisciplinary Journal, 16-21. https://doi.org/10.3126/av.v5i0.15846

Fairoz, F. M., Fairoz, F. M., \& Tanaka, Y. (2010). Entrepreneurial orientation and business performance of small and medium scale enterprises of Hambantota District Sri Lanka. Asian Social Science, 6, 34. https://doi.org/10.5539/ass.v6n3p34 
Gautam, P. R. (2016). Entrepreneurial Orientation and Business Performance of Handicraft Industry: A Study Of Nepalese Handicraft Enterprises. International Journal of Small Business and Entrepreneurship Research, 4, 48-63.

Government of Nepal. (2019). National Economic Census 2018. Kathmandu, Nepal: Central Bureau of Statistics.

Jenatabadi, H. S. (2015). An overview of organizational performance index: definitions and measurements. Available at SSRN 2599439. https://dx.doi.org/10.2139/ssrn.2599439

Johan and Lumpkin, e. a. (2009). Entrepreneurial orientation and business performance: An assessment of past research and suggestions for the future. Entrepreneurship theory and practice, 33, 761-787. https://doi.org/10.1111/j.1540-6520.2009.00308.x

Lumpkin, G., \& Dess, G. G. (1996). Clarifying the entrepreneurial orientation construct and linking it to performance. Academy of management Review, 21, 135-172. https://doi.org/10.5465/amr.1996.9602161568

Lumpkin, G., \& Dess, G. G. (2001). Linking two dimensions of entrepreneurial orientation to firm performance: The moderating role of environment and industry life cycle. Journal of business venturing, 16, 429-451. https://doi.org/10.1016/S0883-9026(00)00048-3

Miller, D. (1983). The correlates of entrepreneurship in three types of firms. Management science, 29, 770-791. https://doi.org/10.1287/mnsc.29.7.770

Mitchell, H. (2002). Strategic worth of human resources: driving organizational performance. Universalia, Canada.

Morris, M. H., Kuratko, D. F., \& Covin, J. G. (2010). Corporate entrepreneurship $\backslash \&$ innovation. Cengage Learning.

Rauch, A., Wiklund, J., Lumpkin, G., \& Frese, M. (2009). Entrepreneurial orientation and business performance: An assessment of past research and suggestions for the future. Entrepreneurship theory and practice, 761-787. https://doi.org/10.1111\%2Fj.1540-6520.2009.00308.x

The World Bank Group. (2020). World Development Indicators. Retrieved August 30, 2020, from http://datatopics.worldbank.org/world-development-indicators/themes/people.html

Tuladhar, J. (1996). Factors affecting Women Entrepreneurship in small and cottage industries in Nepal. ILO.

Venkatraman, N., \& Ramanujam, V. (1986). Measurement of business performance in strategy research: A comparison of approaches. Academy of management review, 11, 801-814. https://doi.org/10.5465/amr.1986.4283976

Wijetunge, W., \& Pushpakumari, M. (2013). Entrepreneurial orientation and business performance of small and medium scale enterprises of western province of Sri Lanka. https://doi.org/10.4038/kjm.v2i2.6550

Wiklund, J., \& Shepherd, D. A. (2011). Where to from here? EO-as-experimentation, failure, and distribution of outcomes. Entrepreneurship Theory and Practice, 35, 925-946. https://doi.org/10.1111\%2Fj.1540-6520.2011.00454.x

Wu, D., \& Zhao, F. (2008). Performance Measurement in the SMEs in the Information Industry. IGI Global. https://doi.org/10.4018/978-1-59904-901-4.ch005

\section{Copyrights}

Copyright for this article is retained by the author(s), with first publication rights granted to the journal.

This is an open-access article distributed under the terms and conditions of the Creative Commons Attribution license (http://creativecommons.org/licenses/by/4.0/). 